\title{
A new record of Podosphaera cardamines (Erysiphales, Erysiphaceae) from Kazakhstan
}

\section{Rakhimova YV}

Institute of Botany and Phytointroduction, Almaty, Kazakhstan

Rakhimova YV 2016 - A new record of Podosphaera cardamines (Erysiphales, Erysiphaceae) from Kazakhstan. Plant Pathology \& Quarantine 6(2), 137-140, Doi 10.5943/ppq/6/2/4

\begin{abstract}
The rare fungus Podosphaera cardamines (Ascomycota, Erysiphales, Erysiphaceae) is recorded on Cardamine macrophylla from the Altai mountain country (east region of Kazakhstan). The fungus is described and illustrated. This is only the second record worldwide of the fungus and the first record on C. macrophylla.
\end{abstract}

Key words - Altai mountains - new host - powdery mildew fungus

\section{Introduction}

Altai mountain country occupies 550,000 square kilometers at the junction of North and Central Asia, within the limits of Russia, Kazakhstan, Mongolia and China. No fewer than 2,700 species of vascular plants have been reported from the area (Kamelin et al. 2005).

Until 1947 mycological collections in the Altai were sporadic. The results of mycological examination of a number of Altai ranges (1947-1975) are presented in volumes of "Flora of spore plants in Kazakhstan" (Nevodovski 1956, Schwartzman 1960, 1964, Vasyagina 1961, Byzova 1967, 1968, 1970, Schwartzman 1973, 1975, Schwartzman \& Kazhiyeva et al. 1976). Since 1978, a survey of belts of the Altai and Saur-Tarbagatai mountains was conducted to study the species composition and ecology of rust fungi (Abiyev 2002).

Studies of Altai mycobiota were continued after a long break in 2006-2008 at the Laboratory of Mycology and Algology Institute of Botany and Phytointroduction. Field trips routes passed through West-Altai Reserve (gorges of the rivers White and Black Uba and their tributaries), Katon-Karagay National Park (valleys of rivers Bukhtarma and the White Berel, vicinity of Uryl and Rakhmanovskiye kluchi) and Markakol Reserve, through the ridges Tarbagatai, Manrak, Saur, Kalba and part of the Kurchum mountain ranges, as well as through the vicinity of UstKamenogorsk and Ridder, Coast Bukhtarma reservoir. As a result of research and compilation of literature data on the territory of Kazakhstan Altai 1,464 taxa of fungi were found belonging to 381 genera, 107 families, 46 orders and 9 classes (Nam et al. 2011).

Several mycological expeditions took place during the program "Inventory of mycobiota and algoflora in Altay Mountains". Approximately 1,200 specimens were collected and added to the mycological herbarium. Various new records of fungi for Kazakhstan were revealed by the identification of these specimens. The present paper, devoted to a contribution to knowledge of Kazakhstan Altai fungi, describes a new record of Podosphaera cardamines. 


\section{Materials \& Methods}

Leaves of plants with typical powdery mildew symptoms were collected during field trips in the Altai Mountains (east region of Kazakhstan). A Canon 600E camera was used for photographing of fungal fruiting bodies. Fresh fruiting bodies were stripped off the leaf surface, placed in a drop of distilled water on a microscope slide without any staining, examined and photographed using a photomicroscope Polyvar with Nomarski interference contrast optics. Thirty measurements of asci, ascospores, chasmothecia and peridium cells were made, with the extremes given in parentheses.

Dried specimens are stored in the herbarium of the Institute of Botany and Phytointroduction, Almaty, Kazakhstan (AA). Duplicates are deposited in the herbarium of the Institute of Biology and Geobotany, Halle (Saale), Germany (HAL).

\section{Results} below.

The identified powdery mildew fungus is new to Kazakhstan, and a description is provided

Podosphaera cardamines (Y. Nomura) U. Braun \& S. Takam., Schlechtendalia 4: 27, 2000.

$\equiv$ Sphaerotheca cardamines Y. Nomura, Taxonomical study of Erysiphaceae of Japan:

19-20, Tokyo 1997.

Description - Mycelium persistent, white, then yellow or greyish (Fig. 1). Chasmothecia scattered or in groups, globose (Fig. 1), 90-103 $\mu \mathrm{m}$ diam. Cells of peridium (Fig. 2) irregularly polygonal, 31.5-38.5 × 22-27 $\mu \mathrm{m}$. Appendages mycelioid, simple or 1-2 times irregularly branched, brown, long, easily breaking off. Asci (Fig. 3) broadly ellipsoidal or ovoid (79.5-88 $\times$ 67-73) $\mu \mathrm{m}, 8$-spored. Ascospores spherical, 13.5-17 × 11.5-16.5 $\mu \mathrm{m}$, colourless.

Known distribution - on Cardamine flexuosa (Brassicaceae); Japan, Hokkaido, Prov. Ishikari, Sapporo; on C. macrophylla, Kazakhstan (this report).

Material examined - Kazakhstan, East Kazakhstan region, Altai mountains, Listvyaga ridge, floodplain of Bukhtarma River, near the village Berel, on Cardamine macrophylla (Brassicaceae), 9 Aug 2008, L.A. Kyzmetova (AA-39F, HAL 2943F); Tarbagatai ridge, near the village Uryl, $49^{\circ} 12^{\prime} 30.8^{\prime \prime}$ N, 86 $15^{\prime} 11.7^{\prime \prime}$ E, on C. macrophylla, 10 Aug 2008, L.A. Kyzmetova (AA-39F).

\section{Discussion}

The size of individual structures of specimens of Podosphaera cardamines from Kazakhstan are comparable to those from Japan (Braun \& Cook et al. 2012) (Table 1).

Table 1 Comparative sizes of asci, ascospores, chasmothecia and peridium cells of Podosphaera cardamines from Japan and Kazakhstan.

\begin{tabular}{lll}
\hline & \multicolumn{1}{c}{ Japan $(\boldsymbol{\mu m})$} & \multicolumn{1}{c}{ Kazakhstan $(\boldsymbol{\mu m})$} \\
\hline Chasmothecia & $80-105$ & $90-103$ \\
Peridial cells & $25-45 \times 17.5-30$ & $31.5-38.5 \times 22-27$ \\
Asci & $70-90 \times 65-75$ & $79.5-88 \times 67-73$ \\
Ascospores & $12.5-18.5 \times 10-17.5$ & $13.5-17 \times 11.5-16.5$ \\
\hline
\end{tabular}



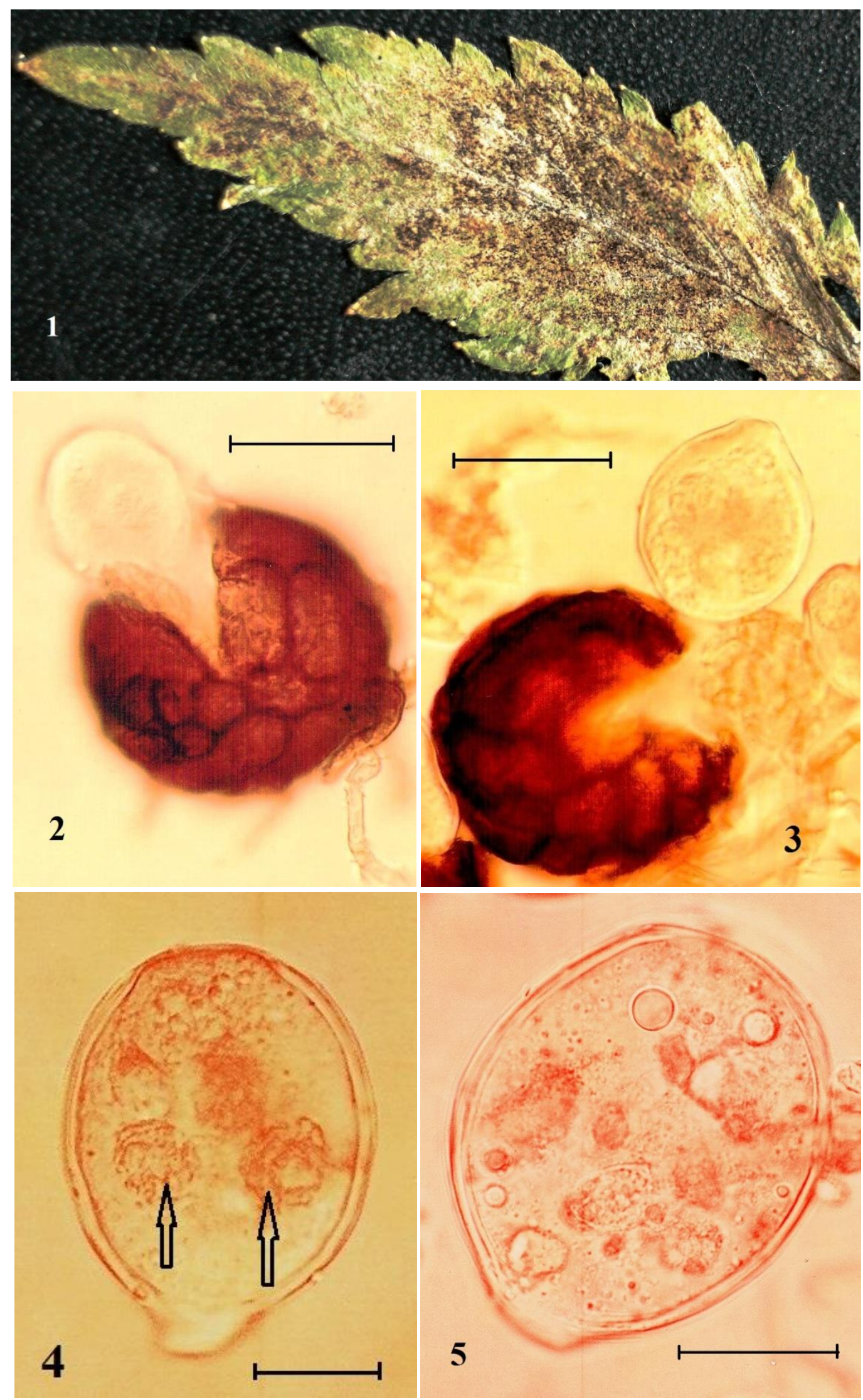

Figs 1-5 - Podosphaera cardamines. 1 Infected part of Cardamine macrophylla leaf. 2 Peridial cells - Bar $=50 \mu \mathrm{m} .3$ Chasmothecium and ascus - Bar $=70 \mu \mathrm{m} .4,5$ Asci with ascospores (arrows) at different stages of development - Bars $=35 \mu \mathrm{m}$. 
This is the first record of Podosphaera cardamines from Kazakhstan and only the second worldwide. Cardamine macrophylla is a new host species for this rare species of powdery mildew fungus.

\section{Acknowledgements}

The author thanks Prof. Dr. U. Braun (Martin-Luther-Universität, Institut für Biologie, Bereich Geobotanik, Herbarium, Halle (Saale), Germany) and Prof. Dr. V.A. Mel'nik (Komarov Botanical Institute, Russian Academy of Sciences, St. Petersburg, Russia) for help in identification of the fungus.

\section{References}

Abiyev SA 2002 - Rust fungi on cereals in Kazakhstan. Almaty, Gylym. [In Russian]

Braun U, Cook RTA 2012 - Taxonomic manual of the Erysiphales (powdery mildews) RBCKNAW Fungal Biodiversity Centre, Utrecht, the Netherlands.

Byzova ZM, Vasyagina MP, Deyeva NG, Kalymbetov BK, Pisareva NF, Schwartzman SR 1967 Flora of spore plants in Kazakhstan. Fungi imperfecti, Sphaeropsidales. Volume 5, part 1, Alma-Ata. [In Russian]

Byzova ZM, Vasyagina MP, Deyeva NG, Kalymbetov BK, Pisareva NF, Schwartzman SR 1968 Flora of spore plants in Kazakhstan. Fungi imperfecti, Sphaeropsidales. Volume 5, part 2, Alma-Ata. [In Russian]

Byzova ZM, Vasyagina MP, Deyeva NG, Kalymbetov BK, Pisareva NF, Schwartzman SR 1970 Flora of spore plants in Kazakhstan. Fungi imperfecti, Sphaeropsidales. Volume 5, part 3, Alma-Ata. [In Russian]

Kamelin RV, Kuzev MG, Tikhonov DV, Shaulo DN, Shmakov AI, Viane RLL 2005 - Flora of Altai. Volume 1, Barnaul, AzBuka. [In Russian]

Nam GA, Rakhimova EV, Yermekova BD, Abiyev SA, Yessengulova BZ, Kyzmetova LA 2011 Fungi of Kazakhstan Altai (list of species). Almaty, Intellect. [In Russian]

Nevodovski GS 1956 - Flora of spore plants in Kazakhstan. Rust fungi. Volume 1, Alma-Ata. [In Russian]

Schwartzman SR 1960 - Flora of spore plants in Kazakhstan. Smut fungi. Volume 2, Alma-Ata. [In Russian]

Schwartzman SR 1964 - Flora of spore plants in Kazakhstan. Heterobasidiomycetes and autobasidiomycetes. Volume 3, Alma-Ata. [In Russian]

Schwartzman SR, Kazhiyeva NT 1976 - Flora of spore plants in Kazakhstan. Discomycetes. Volume 9, Alma-Ata. [In Russian]

Schwartzman SR, Vasyagina MP, Byzova ZM, Filimonova NM 1973- Flora of spore plants in Kazakhstan. Fungi imperfecti (Deuteromycetes). Moniliales. Volume 8, part 1, Alma-Ata. [In Russian]

Schwartzman SR Vasyagina MP, Byzova ZM, Filimonova NM 1975 - Flora of spore plants in Kazakhstan. Fungi imperfecti (Deuteromycetes). Moniliales. Volume 8, part 2, Alma-Ata. [In Russian]

Vasyagina MP, Kuznetsova MN, Pisareva NF, Schwartzman SR 1961 - Flora of spore plants in Kazakhstan. Powdery mildew fungi. Volume 3, Alma-Ata. [In Russian] 